\title{
POUŽITÍ NEDESTRUKTIVNÍCH METOD A REGRESNÍCH VZTAHŮ V DIAGNOSTICE STAVEBNÍCH KONSTRUKCÍ
}

\author{
USE OF NON-DESTRUCTIVE METHODS AND REGRESSION EQUATION \\ IN DIAGNOSTICS OF BUILDING
}

\author{
Sabina Olejková ${ }^{*}, 1$, Kristýna Hrabová $^{1}$, Dominik Masařík ${ }^{1}$
}

${ }^{*} 157411 @$ vutbr.cz

${ }^{1}$ Vysoké učení technické v Brně, Fakulta stavební, Veveři 331/95, 60200 Brno, Česká republika

\begin{abstract}
Abstrakt
Vzhledem ke zvyšujícímu se počtu rekonstrukcí historických staveb v posledních letech, roste i význam šetrnějších nedestruktivních metod. V budoucnosti by bylo vhodné vytvořit vztah nebo porovnání výsledků nedestruktivních zkoušek a zkoušek destruktivních. Tento vztah by určil míru rizika (koeficient nebo odchylku) v prrípadě, že by při diagnostice stavebních konstrukcí byly zvoleny pouze metody destruktivní. To by mohlo znamenat velký posun $\mathrm{v}$ rámci nedestruktivního testování. Jednalo by se jak o šetrnější a ekologičtější variantu testování stavebních konstrukcí i vzhledem k životnímu prostředí.
\end{abstract}

\section{Klíčová slova}

Nedestruktivní testování železobetonových konstrukcí, ultrazvuková impulsová metoda, metoda odrazových tvrdoměrů, regresní vztahy

\begin{abstract}
Due to the increasing number of reconstructions of historic buildings in recent years, the importance of more enviromentally friendly non-destructive methods is also growing. In the future, it would be appropriate to establish relationship or compare the results of non-destructive tests and destructive tests. This relationship would determine the degree of risk (constant or deviation) if only destructive methods were chosen in the diagnosis of building structures. This could mean a major shift in non-destructive testing. If would be both a more enviromentally friendly variant of testing building structures with regard to the enviroment.
\end{abstract}

\section{Key words}

Non-destructive testing of the reinforced structures, ultrasonic pulse velocity, rebound hammer test, regression equation

\section{1 ÚVOD}

Často jsou stavební konstrukce vystaveny nepř́iznivým podmínkám, které mohou zapříčinit jejich nevyhovující stav. Posoudit stav stavebních konstrukcí lze dle normy ČSN ISO 13822 [1], ve které se uvádí mezinárodně platné postupy hodnocení spolehlivosti existujících konstrukcí. V rámci hodnocení stavebních konstrukcí se jejich aktuální stav posuzuje na základě vhodně zvolených diagnostických metod, at' už se jedná o př́mé či nepřímé metody.

Standardně se u nově vybudovaných konstrukcí kvalita betonu kontroluje již po čas samotné výroby na vytvořených zkušebních tělesech. Z jednotlivých záměsí lze určit danou pevnost $\mathrm{v}$ tlaku, která byla pro výstavbu požadována a navržena. Tedy zhotovit zkušební tělesa a stanovit tak danou pevnost je u nových konstrukcí snadné. Poměrně složitější je to v případě konstrukcí starších a zejména se to týká těch historických. V posledních letech byly upřednostňovány metody destruktivní (jádrové vývrty) a semidestruktivní (zkoušky tvrdoměrné). Ultrazvukové zkoušky byly dlouho dobu pouze doplňkovou metodou pro referenční zkoušky pevnosti na jádrových vývrtech. Díky velkému množství historických staveb roste zájem o diagnostiku především s využitím nedestruktivních metod, což není vždy možné. Další alternativou, kde nedochází ve větší míře k poškození konstrukcí, je volba metody odrazových tvrdoměrů, kde je však potřebné obroušení povrchu, 
a proto se nejedná o zcela šetrnou metodu. I tak není při jejich použití zásah do konstrukce tak markantní, jako je tomu v prrípadě metod destruktivních. Nedestruktivní zkoušky jsou vhodnou volbou při stavební diagnostice konstrukcí, kde není možný zásah ve větší míře. Jsou rychlé, přesné a lze je opakovat. Samozřejmě jejich hlavní dominanta spočívá $\mathrm{v}$ jejich nedestruktivním charakteru, kdy při jejich použití nedochází k žádnému poškození. Podobnému tématu je věnována pozornost v článku „Prediction of concrete strength by non-destructive testing in old structures: Effect of core number on the reliability of prediction“ [2]. Z výsledků nedestruktivních zkoušek je možné jednoduše vypočítat nejen pevnost $\mathrm{v}$ tlaku, jejíž znalost je velmi důležitá $\mathrm{k}$ určení stávajícího stavu konstrukce, ale také dynamický modul pružnosti. Ultrazvuková impulsová metoda poskytuje okamžité výsledky i v grafické podobě a stav konstrukce lze tedy odhadnout již v průběhu samotného měření. Avšak stále musí být nedestruktivní zkoušky vždy ověřeny a porovnány s výsledky destruktivních zkoušek, při nichž jsou odebrány jádrové vývrty. Zde však dochází ke znehodnocení vizuálního charakteru, a také (při nevhodné volbě zkušebního místa) může dojít ke statickému narušení konstrukce. Odebrané jádrové vývrty slouží k přímému stanovení pevnosti $\mathrm{v}$ tlaku. $\mathrm{V}$ př́padě volby destruktivních metod, by měly být vývrty odebrány sofistikovaně. Nejdříve by měl být určen záměr, a také je nutno si uvědomit, z jakých míst lze tyto vzorky odebrat (je-li to vưbec možné), aby nedošlo k významnému porušení konstrukce nebo její části.

Aby bylo v budoucnosti možné použít ultrazvukovou impulsovou metodu nebo i metodu odrazových tvrdoměrů se stejnou efektivitou jako je tomu u odebraných jádrových vývrtů, bude zapotřebí stanovit přijatelnou míru rizika, v případě použití pouze metod nepřímých. To znamená stanovení např. odchylky (nebo koeficientu), která by nám ukázala, jak moc se výsledky získané z metod nedestruktivních liší od výsledků z destruktivních zkoušek. V případě, že bude tato odchylka minimální, bude možné přímé (destruktivní) i neprrímé (nedestruktivní) metody považovat za rovnocenné. Světlo na konci tunelu lze najít v loňském vydání normy ČSN EN 13791 [3], která prošla zásadní revizí a vrátila tak v moderní diagnostice důležitou roli nedestruktivním metodám.

Tento př́íspěvek bude zaměřen na použití nedestruktivních a semidestruktivních metod na námi vytvořených zkušebních tělesech. Při diagnostice ultrazvukovou impulsovou metodou bude použit př́stroj Pundit PL 200 PE [4] a v př́padě odrazových tvrdoměrů se bude jednat o tvrdoměr typ Silver Schmidt, jejichž charakteristika i princip je popsán v [5]. Pro určení nejslabších míst konstrukce by v budoucnu mohlo sloužit právě nedestruktivní zkoušení, nebot' především u rozsáhlejších konstrukcí by z hlediska efektivity a nákladnosti nemohly být jádrové vývrty odebrány ze všech míst, nehledě na výrazné poškození konstrukce nadměrným odběrem vzorků. Pomocí nedestruktivních metod lze efektivně zmapovat vlastnosti celé konstrukce a vytipovat nejslabší místa v konstrukci pro kontrolní odběry vzorků jádrovým vrtáním, což je sice nutné z hlediska upřesnění a vyloučení hrubých chyb, ovšem pokud možno v co nejmenším rozsahu. Došlo by tak k optimalizaci počtu jádrových vývrtů a minimalizaci zásahů do stavebních konstrukcí a jejich znehodnocení.

\section{METODIKA}

\section{Ultrazvuková impulsová metoda}

Princip této metody spočívá v opakovaném vysílání ultrazvukových vln do povrchu konstrukce budičem a následném sledování prošlých impulsů přijímačem na konci samotného prvku. Jestliže ultrazvuková vlna procházející betonem narazí na rozhraní beton-vzduchová mezera, tak bude zabráněno přímému průchodu impulsu. Impuls bude muset tuto překážku obejít a prodlouží se tak celková dráha impulsu. Č́m vyšší je kvalita materiálu (modul pružnosti, hustota a integrita betonu), tím vyšší je rychlost pulzu. Ultrazvuková metoda má také svůj potenciál při odhalování poruch uvnitř betonových prvků, at' již mají charakter technologický či statický. Metoda je nejlépe využitelná u konstrukčních prvků přístupných z obou stran, jako jsou sloupy, pilíŕe nebo nosníky. Při vyhodnocování záleží také na typu prozvučování konstrukce - přímé, nepřímé a poloprrímé. Nejen typ prozvučování konstrukce, ale také vhodné zvolení sond je velice důležité (u malých základen to bývá asi $150 \mathrm{kHz}$ a u silnějších prvků třeba i $54 \mathrm{kHz}$ ) a akustického vazebného prostředku. Při měření je vždy známa dráha (odpovídající rozměrům konstrukce) a čas, za který projde ultrazvuková vlna měřeným prvkem. Z těchto charakteristik je tedy možné vypočíst odpovídající rychlost. Měření mohou být ovlivněna mnoha faktory, jako jsou dutiny, mezery nebo také výztuž nacházející se ve dráze vyslaného impulsu. Proto je vhodné před samotným měřením výztuž lokalizovat např. pomocí elektromagnetických indikátorů. Nízká kvalita betonu se považuje pro beton s rychlostí nižší než $3000 \mathrm{~m} . \mathrm{s}^{-1}$, naopak vysokou kvalitu betonu značí beton s rychlostí okolo $4500 \mathrm{~m} \cdot \mathrm{s}^{-1}[6],[7]$. 


\section{Metoda odrazového tvrdoměru}

V dnešní době se na stavebním trhu objevuje hned několik typů tvrdoměrů, které se používají na různé typy konstrukcí. Největší sortiment tvrdoměrů lze bezpochyby najít u firmy Proceq SA. S rozvojem vysokopevnostních betonů došlo k vývoji nejmodernějších přístrojů typu Silver Schmidt $\mathrm{N}$ a L. Testování pomocí Schmidtova kladívka je jednou z nejčastěji používaných metod pro nedestruktivní zkoušení betonu a stavebních dílců [5]. Měřní je velice snadné, a pokud je prováděno správně, je metoda velmi spolehlivá. Na základě zjištěného ukazatele tvrdosti je možné stanovit velikost krychelné pevnosti v tlaku. Avšak i u této metody existuje řada faktorů, které mohou ovlivnit výsledné měření jako odlišná tvrdost betonu na povrchu a uvnitř betonu u starších konstrukcí nebo použití plastifikátoru u konstrukcí nových. I zde je tedy nutné provést upřesnění na jádrových vývrtech [8], [9].

\section{EXPERIMENT}

Samotný experiment byl proveden na železobetonových sloupech s rozměry 300 x 200 x 1200 mm. Hlavní použitá výztuž nacházející se v rozích sloupů (s krytím $30 \mathrm{~mm}$ ) byla B500B o průměru $16 \mathrm{~mm}$. U třmínků byl zvolen profil $6 \mathrm{~mm}$ a taktéž typ výztuže B500B. Celkem bylo vybetonováno 8 zkušebních vzorků tvaru krychle o délce hrany $150 \mathrm{~mm}$ - Obr. 3, které byly zkoušeny pomocí ultrazvukového přistroje a odrazového tvrdoměru Obr. 2. Aby bylo možné provést co nejlepší simulaci reálné konstrukce, byly sloupy vybetonovány z různých druhů betonů lišících se obsahem cementu. Celkem bylo vyrobeno 6 záměsí, kde 1 . a 2. záměs byla vyrobena z betonu vyšší kvality a ve 3. - 5. záměsi byl beton méně kvalitní - nižší obsah cementu. Poslední záměs byla vyrobena opět z betonu vyšší kvality. Z každé záměsi bylo odebráno alespoň jedno zkušební těleso. Po pečlivém uskladnění a ošetření vzorků byly na tělesech provedeny nedestruktivní zkoušky. Návrh rozložení betonové směsi je zobrazen na Obr. 1 .
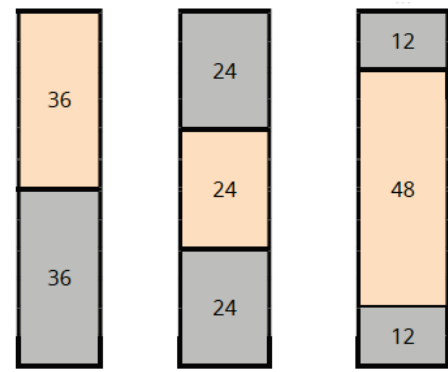

Obr. 1 Sloupy s návrhovým vyobrazeným rozdělením betonových směsí (barvy představují směsi, čísla pak objemy).

Vyrobené sloupy byly zkoušeny pouze nedestruktivně vzhledem $\mathrm{k}$ jejich použití $\mathrm{v}$ rámci dalších experimentů. Pro destruktivní zkoušky byly určeny vyrobené krychle. Ovšem z důvodu simulace reálné diagnostiky konstrukce byla z každé krychle odvrtána dvě válcová tělesa o průměru $75 \mathrm{~mm} \mathrm{~s}$ označením X. 1 (dolní část betonové krychle) a X. 2 (horní část tělesa).
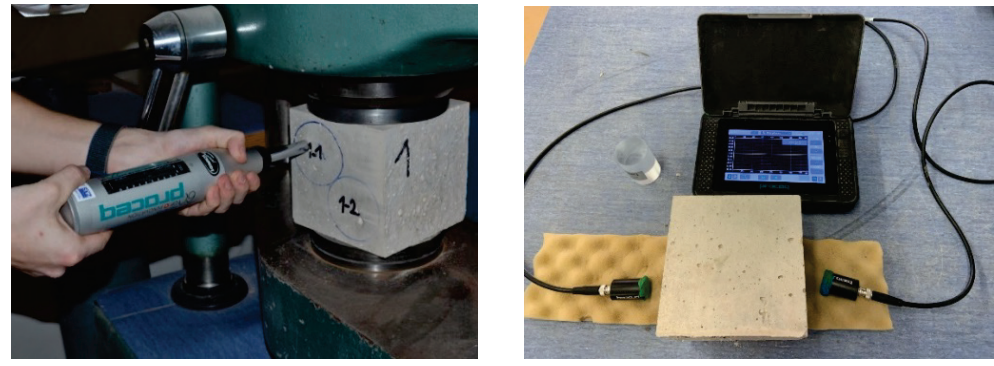

Obr. 2 Použití tvrdoměrné metody (Silver Schmidt) na zkušebních krychlích - vlevo, prozvučování betonové krychle pomocí ultrazvukového př́stroje (Pundit PL 200 PE) - vpravo. 
Ze zbytků každé krychle byla vyřezána 1 krychlička o délce hrany $50 \mathrm{~mm}$ a 1 trámeček s rozměry 50 x 50 x 95 mm. Při následném provádění zkoušek se jednoznačně potvrdil vliv horšího zhutnění na pokles pevnosti v tlaku v horní části těles.

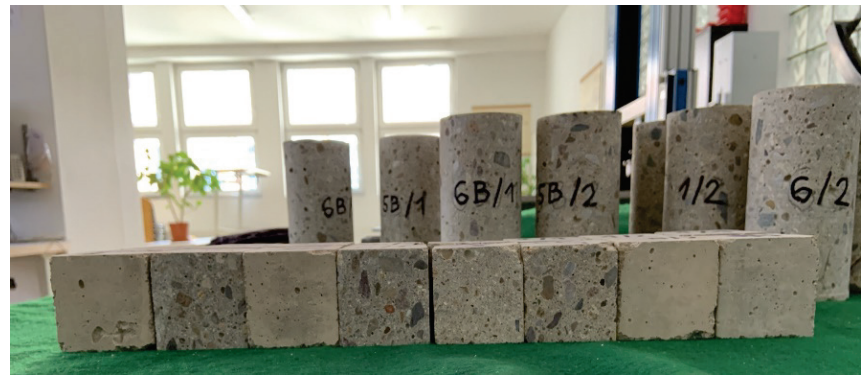

Obr. 3 Zkušební tělesa tvaru krychle (o délce hrany $150 \mathrm{~mm}$ ) a jádrové vývrty (průměru $75 \mathrm{~mm}$ ).

U všech nově vzniklých těles byly zjištěny základní charakteristiky - rozměry, hmotnost a pevnost v tlaku. $\mathrm{Na}$ závěr byla všechna data vyhodnocena a porovnána mezi sebou a byly vypočteny regresní vztahy mezi jednotlivými metodami.

\section{VÝSLEDKY}

Výsledky z ultrazvukových měření a z odrazových tvrdoměrů provedené na vyrobených sloupech jsou znázorněny graficky na Obr. 4. Výsledky ukázaly, že přesnější rozdělení betonových směsí v jednotlivých sloupech byly naměřeny z ultrazvukového př́ístroje (vlevo).

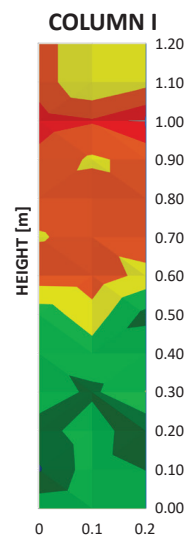

- $4200-4300=4100-4200$

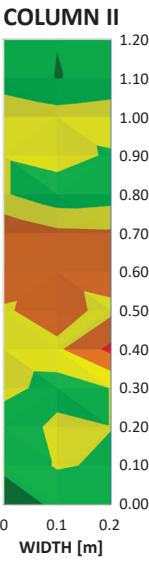

$\mathrm{t}[\mu \mathrm{s}]$
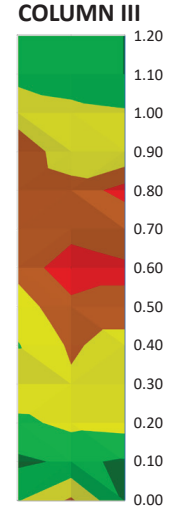

0.10 .2

$=4000-4100=3900-4000 \quad-3800-3900$

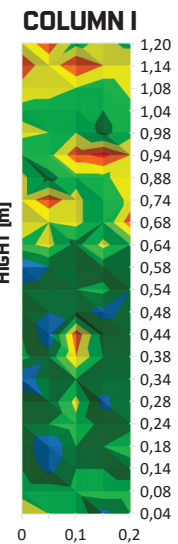

COLUMN I

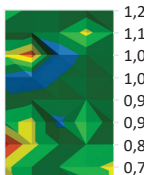

\section{COLUMN II}

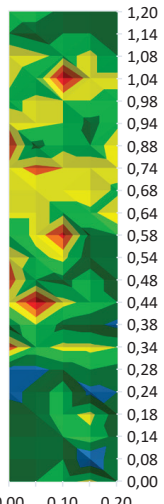

$\begin{array}{lll}0,00 & 0,10 & 0,20\end{array}$

$\begin{array}{lll}0,00 & 0,10 \quad 0,20\end{array}$

WIDTH [m]

— 41-44 - 38-41

๑ [

Obr. 4 Vlevo - výsledky rychlosti ultrazvukových vlnění vyhodnocené z ultrazvukového přistroje

Pundit PL 200 PE vyjádřené v barevné škále; vpravo - výsledky hodnot odrazu z odrazových tvrdoměrů Silver Schmidt vyjádřené v barevné škále.

Z mechanicko - fyzikálních vlastnosti zkušebních těles byly vytvořeny lineární regresní vztahy. Vyhodnocení bylo zaměřeno na lineární regresní vztahy mezi čísly odrazu, která by měla korespondovat s pevností v tlaku s 95\% spolehlivostí. Výsledky lineární regrese jsou vyobrazeny na Obr. 5. $\mathrm{Z}$ předběžných regresních křivek je patrné, že koeficient determinace $\left(\mathrm{r}^{2}\right)$ je poměrně nízký. 


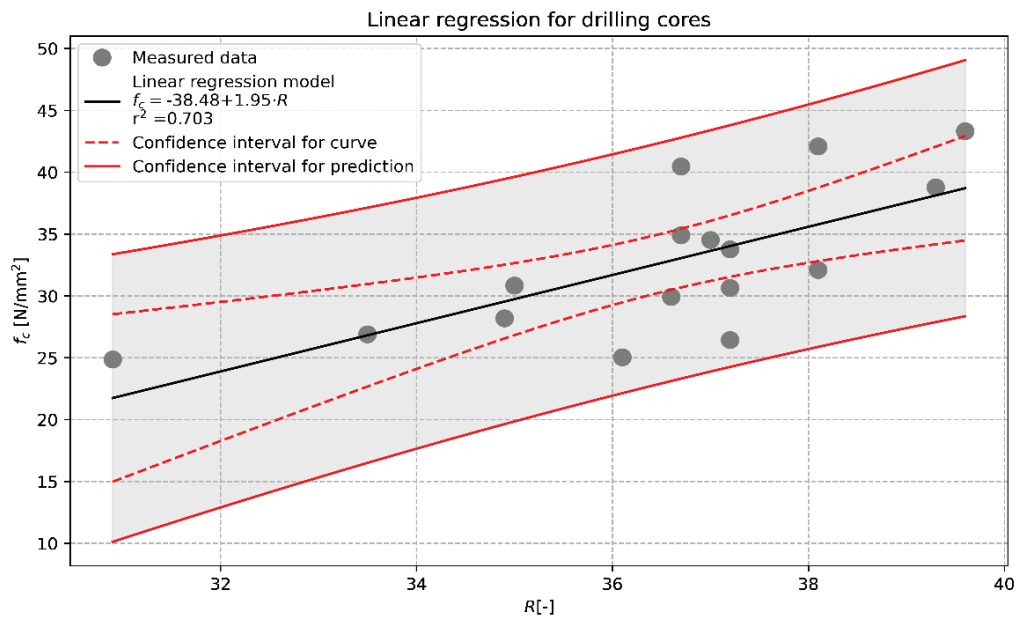

Obr. 5 Lineární regresní model pro jádrové vývrty vytvořený ze závislosti mezi čísly odrazu z tvrdoměrných zkoušek a pevností v tlaku.

\section{ZÁVĚR}

Výsledky semidestruktivních a nedestruktivních metod provedených na železobetonových sloupech ukázaly, že přesnější uspořádání jednotlivých směsí betonu odhalila metoda ultrazvuková. Výsledky z ultrazvukového přístroje se téměř shodují s návrhovým rozdělením betonové směsi v tělesech. Použitím této metody lze odhadnout místa v konstrukci s horšími vlastnostmi. Výsledky získané z odrazového tvrdoměru jsou také velmi blízké návrhovému schématu, i když tvrdoměrná metoda není tak citlivá jako metoda ultrazvuková. Zvýšení citlivosti lze u odrazových metod do jisté míry dosáhnout zvýšením počtu odrazových míst. To, že je zkoušen pouze povrch konstrukce, je jeden z faktorů negativně ovlivňujících výsledky měření. V př́padě, jsou-li využity pouze nedestruktivní metody bez upřesnění výsledků pomocí jádrových vývrtů, vzniká poměrně vysoké riziko určení nepřesných mechanicko-fyzikálních vlastnosti betonu. Toto riziko pak může vést $\mathrm{k}$ nesprávnému zhodnocení konstrukce. Proto je vhodné využít nedestruktivního měření převážně pro lokalizaci míst, ze kterých mohou být následně odebrané jádrové vývrty. Aby bylo možné vytvořit regresní vztahy, je zapotřebí regresní vztahy vytvořit zejména $\mathrm{z}$ míst s nejhoršími a nejlepšími vlastnostmi betonu, kde bude provedeno alespoň 8 jádrových vývrtů. Jestliže není možné zasahovat do stavebních konstrukcí, měly by nedestruktivní metody sloužit $\mathrm{k}$ výběru pouze nejslabších míst. $\mathrm{V}$ těchto místech by mělo dojít $\mathrm{k}$ cílenému odběru minimálního možného počtu jádrových vývrtů, potřebných k vyhodnocení [10].

\section{Poděkování}

Tento příspěvek vznikl za finanční podpory specifického výzkumu č. FAST-J-21-7509 Vysokého učení technického v Brně.

\section{Použité zdroje}

[1] ISO 13822: 2015 Zásady navrhování konstrukcí - Hodnocení existujících konstrukcí. Praha: UNMZ, 2014.

[2] Y. Boussahoua, S. Kenai and K. Ali-Benyahia, Prediction of concrete strength by non-destructive testing in old structures: Effect of core number on the reliability of prediction, MATEC Web of Conferences 149, 02007 (2018).

[3] ČSN EN 13791 Posuzování pevnosti betonu v tlaku v konstrukcích a v prefabrikovaných betonových dílcích. Praha: ÚNMZ, 2020.

[4] Proceq: PUNDIT® PL-200 ULTRASONIC PULSE VELOCITY. Switzerland, 2014. https://www.proceq.com/uploads/tx_proceqproductcms/import_data/files/Pundit\%20PL2_Sales\%20Flyer_English_high.pdf 
[5] Papworths Construction Testing Equipment, Silver Schmidt Live. Available online: https://www.pcte.com.au/silver-schmidt-rebound-hammer (accessed on 30 June 2021).

[6] G. Karaiskos, A. Deraemaeker, D.G. Aggelis and D. Van Hemelrijck, Monitoring of concrete structures using the ultrasonic pulse velocity method. Smart Materials and Structures, Volume 24, Issue 11, article id. 113001 (2015).

[7] K. A. Snyder, L.-P. Sung, G. S. Cheok, Nondestructive Testing (NDT) and Sensor Technology for Service Life Modeling of New and Existing Concrete Structures. National Institute of Standards and Technology. U. S. Department of Commerce. 12/2013.

[8] P. Cikrle, D. Kocáb, J. Červenka, Tvrdoměrné zkoušení betonu - část 2. Časopis Beton TKS, 2019, roč. 19 , č. 2, s. 14-18.

[9] K. Malý, M. Jarolím, P. Huňka, Tvrdoměrné metody zkoušení betonu - př́klad z praxe. Časopis Beton TKS, 2019, roč. 19 , č. 6, s. 38-40.

[10] J. Niedoba, K. Hrabová, D. Masařík, S. Hüblová, P. Cikrle, Non-destructive diagnostic methods and reggression equation during building structure diagnosis. SGEM 2021. International multidisciplinary geoconference SGEM. Bulgaria: SGEM Conference, 2021. ISSN: 1314-2704. (v tisku) 